\title{
Pengaruh Pemberian Pakan Cacing Tanah (Lumbricus rubellus) dan Pelet Terhadap Pertumbuhan dan Perkembangan Benih Ikan Lele Dumbo (Clarias gariepinus)
}

\author{
Riko Irwanto*, Novia Lesti \\ Program Studi Biologi, Universitas Bangka Belitung \\ *Email: rikoirwanto170392@gmail.com
}

DOI: https://doi.org/10.33369/pendipa.5.2.115-121

\begin{abstract}
Catfish is a freshwater fish commodity that is currently being sought after by many people for consumption. The demand for catfish is increasing day by day. Catfish farming is one business that can develop rapidly. In the fish culture system, there are several factors such as fish growth. Factors that greatly affect the growth and development of fish are feed. The research objectives were to determine the effect of different feeding on the growth and development of African catfish (Clarias gariepinus) and to determine the nutritional content of types of feed for African catfish (Clarias gariepinus). This research was conducted in Desa Tugang, Kelapa District, West Bangka Regency, Bangka Belitung Islands Province. The research was conducted by observing the growth of catfish seeds which included total length, total weight, height, head length, tail length and dorsal fin length. The development of catfish seeds observed was the activity of moving and eating feed for 3 weeks of maintenance. The results of the study were calculated using the absolute weight growth formula and the absolute length growth formula. The study design used a completely randomized design (CRD) using 2 variations of feed with 5 times of repetition. The data obtained were analyzed using analysis of variance (ANOVA), to determine whether or not the feed given was significant or not on the growth of catfish. The results showed that catfish seeds fed natural earthworms had a faster growth and better development rate compared to pellet-fed catfish seeds. The ANOVA test results different feeding showed a significant effect on total length growth weight, total weight, head length, and dorsal fin length (F count $>F$ table). Meanwhile, height and tail length did not have a significant effect ( $F$ count $<F$ table).
\end{abstract}

Keywords: Growth, Development, Catfish, Feed.

\begin{abstract}
ABSTRAK
Ikan lele merupakan salah satu komuditas ikan air tawar yang saat ini telah banyak dicari oleh masyarakat untuk dikonsumsi. Pada sistem pembudidayaan ikan, terdapat beberapa faktor yang perlu diperhatikan seperti pertumbuhan ikan Faktor yang sangat mempengaruhi pertumbuhan dan perkembangan ikan adalah pakan. Tujuan penelitian adalah mengetahui pengaruh pemberian pakan yang berbeda terhadap pertumbuhan dan perkembangan benih ikan lele dumbo (Clarias gariepinus) dan mengetahui kandungan nutrisi jenis-jenis pakan ikan lele dumbo (Clarias gariepinus). Penelitian ini dilaksanakan di Desa Tugang, Kecamatan Kelapa, Kabupaten Bangka Barat, Provinsi Kepulauan Bangka Belitung. Penelitian dilakukan dengan mengamati pertumbuhan benih ikan lele yang meliputi, panjang total, berat total, tinggi badan, panjang kepala, panjang ekor dan panjang sirip dorsal. Perkembangan benih ikan lele yang diamati adalah keaktifan bergerak dan menyantap pakan selama 3 minggu pemeliharaan. Hasil penelitian dihitung dengan rumus pertumbuhan berat mutlak dan rumus pertumbuhan panjang mutlak. Rancangan penelitian ini menggunakan rancangan acak lengkap (RAL) menggunakan 2 variasi pakan dengan 5x pengulangan. Data yang diperoleh dianalisa menggunakan analysis of variance (ANOVA). Hasil penelitian menunjukkan bahwa benih ikan lele dumbo yang diberi pakan alami cacing tanah memiliki laju pertumbuhan dan perkembangan yang lebih cepat jika dibandingkan dengan benih ikan lele yang diberi pakan pelet. Hasil uji
\end{abstract}


ANOVA pemberian pakan berbeda menunjukkan pengaruh nyata terhadap bobot pertumbuhan panjang total, berat total, panjang kepala, dan panjang sirip dorsal ( $\mathrm{F}$ hitung $>\mathrm{F}$ tabel). Sedangkan untuk tinggi badan dan panjang ekor tidak berpengaruh nyata ( $\mathrm{F}$ hitung $<\mathrm{F}$ tabel).

Kata kunci: Pertumbuhan, Perkembangan, Ikan lele, Pakan.

\section{PENDAHULUAN}

Ikan air tawar merupakan salah satu komuditas perikanan yang saat ini telah banyak dicari oleh masyarakat untuk dikonsumsi. Salah satu jenis ikan air tawar yang banyak digemari oleh masyarakat adalah ikan lele. Permintaan terhadap ikan lele yang semakin harinya semakin meningkat. Kandungan protein ikan lele yang cukup tinggi menjadi alasan masyarakat gemar mengkonsumsi ikan lele. Berdasarkan hasil penelitian Syafruddin (2016), kandungan protein pada ikan lele di pasar yaitu sebesar 13,182\%. Ikan lele biasanya diambil dari perairan bebas. Namun, seiring berjalannya waktu sudah banyak upaya pembudidayaan ikan lele yang dilakukan oleh peternak ikan. Hal itu dilakukan sebagai upaya untuk mencegah menurunnya populasi ikan lele serta menjaga kelestariannya dialam bebas. Selain itu, mudahnya pembududayaan ikan lele menjadi alasan usaha budidaya ikan banyak dilakukan.

Budidaya ikan lele merupakan salah satu usaha yang dapat berkembang dengan cepat. Pada sistem pembudidayaan ikan, terdapat beberapa faktor yang perlu diperhatikan seperti pertumbuhan ikan. Sedangkan faktor yang mempengaruhi pertumbuhan ikan adalah pakan. Pemberian jenis pakan yang tepat dan berkecukupan dapat mempercepat pertumbuhan ikan lele yang dibudidaya. Menurut Mudjimam (2008), pakan merupakan sumber energi dan materi untuk menopang kelangsungan hidup dan pertumbuhan ikan. Pakan terdiri atas pakan alami, pakan buatan dan pakan tambahan. Pakan alami bagi ikan lele adalah cacing tanah. Cacing tanah merupakan salah satu pakan alami yang paling disukai oleh ikan air tawar. Cacing tanah memiliki kandungan protein yang tingi sehingga sangat baik ikan air tawar. Menurut Julendra (2007), kandungan protein pada cacing tanah adalah sekitar 60-72 \%. Sedangkan yang termasuk pakan buatan adalah pakan pelet. Pakan pelet adalah makanan ikan yang dibuat dari campuran bahan-bahan alami atau bahan olahan yang kemudian diolah. Pakan pelet biasanya dibuat dalam bentuk tertentu sehingga dapat menarik ikan dan mempermudah ikan dalam melahapnya. Pakan pelet komersial yang biasa digunakan mengandung $33 \%$ protein, $5 \%$ lemak dan $6 \%$ karbohidrat.

Berdasarkan uraian di atas, pakan alami cacing tanah (Lumbricus rubellus) dan pakan pelet dapat dijadikan sebagai pakan utama bagi peternak ikan. Namun, informasi mengenai pengaruh pakan tersebut terhadap pertumbuhan ikan lele masih belum memadai. Maka dari itu penelitian ini dilakukan sebagai sumber informasi bagi peternak ikan lele nantinya tentang pengaruh pemberian pakan terhadap pertumbuhan ikan yang dibudidaya.

\section{METODE PENELITIAN}

\section{Waktu dan Tempat}

Penelitian dilaksanakan pada bulan Juni hingga Agustus 2020 di Desa Tugang, Kecamatan Kelapa, Kabupaten Bangka Barat, Provinsi Kepulauan Bangka Belitung.

\begin{abstract}
Alat dan Bahan
Alat

Penelitian ini dilakukan dengan beberapa tahapan. Alat yang digunakan dalam persiapan media pemeliharaan meliputi toples plastik dan spidol. Pemeliharaan ikan lele dilakukan dengan
\end{abstract}


menggunakan alat yaitu 10 wadah pemeliharaan, timbangan digital dan mistar. Pengukuran Mikroklimat dilakukan dengan mengguanakan alat thermometer. Pemberian pakan alat yang digunakan yaitu timbangan digital. Pertumbuhan dan perkembangan ikan alat yang digunakan yaitu timbangan digital dan penggaris.

\section{Bahan}

Penelitian ini terdiri dari beberapa tahapan. Bahan yang digunakan dalam persiapan media pemeliharaan adalah air bersih. Pemeliharaan ikan lele dilakukan dengan bahan 10 ekor benih ikan lele, cacing tanah dan pakan pelet. Pengukuran minkroklimat, bahan yang digunakan adalah kertas lakmus. Pemberian pakan bahan yang digunakan yaitu cacing tanah dan pakan pelet. Pertumbuhan dan perkembangan ikan lele bahan yang digunakan yaitu ikan lele yang dipelihara.

\section{Prosedur Kerja \\ Persiapan Media Pemeliharaan}

Wadah pemeliharaan benih ikan lele berupa wadah plastik dengan ukuran yang sama sebanyak 10 buah. Sebelum digunakan toples platik dicuci kemudian dikeringkan terlebih dahulu. Setelah itu wadah diisi dengan air dan diletakkan pada tempat dengan suhu yang sama tanpa diberi tumbuhan air.

\section{Pemeliharaan Ikan Lele}

Benih ikan lele yang digunakan adalah benih lele usia 5 minggu yang memiliki berat awal 12,2 gram dengan panjang total tubuh 3,6-4,4 cm. Benih ikan lele yang digunakan dalam percobaan ini berasal dari peternakan lele yang terdapat di desa Bakit, kecamatan Paritiga, kabupaten Bangka Barat, Provinsi kepulauan Bangka Belitung. Benih dimasukkan kedalam 10 wadah pemeliharaan masing-masing 1 ekor pada satu wadah dengan 2 perlakuan (pakan pellet dan pakan cacing tanah). 5 wadah (5 ulangan) diberi pakan pellet dan 5 wadah (5 ulangan) lainya pakan cacing tanah. Pemeliharaan dilakukan sampai usia 2 bulan ( 8 minggu).

\section{Pengukuran Mikroklimat}

Pemgukuran mikroklimat dilakukan secara langsung pada lokasi pemeliharaan benih ikan lele dumbo.

\section{Pemberian Pakan}

Pakan yang digunakan dalam penelitian ini adalah pakan alami (cacing tanah) dan pakan buatan (pelet). Pakan diberikan setiap 5 jam sekali sebanyak 2,5 gram untuk 1 kali pemberian pakan dengan 3 kali pemberian, yaitu pukul 06.00 WIB, 11.00 WIB dan 16.00 WIB.

\section{Pertumbuhan ikan}

Laju pertumbuhan spesifik dan laju pertambahan panjang sebagai data pertumbuhan ikan diukur pada tiap 7 hari sekali untuk mengetahui pengaruh dari pemberian pakan terhadap pertumbuhan dan perkembangan ikan lele dumbo. Data yang diambil berupa morfologi ikan yaitu: panjang kepala, tinggi badan, panjang total, panjang ekor dan panjang sirip dorsal. Rumus pertumbuhan panjang mutlak dihitung dengan rumus Effendi et.al (2006):

$$
\mathrm{Lm}=\mathrm{L}_{\mathrm{t}}-\mathrm{L}_{0}
$$

Keterangan:

$\mathrm{Lm}=$ pertumbuhan panjang $(\mathrm{cm})$

$\mathrm{Lt}=$ pertumbuhan ikan pada waktu akhir $(\mathrm{cm})$

$\mathrm{L}_{0}=$ pertumbuhan ikan pada waktu awal $(\mathrm{cm})$

Sedangkan untuk rumus laju pertumbuhan berat mutlak ikan (W) dihitung dengan menggunakan rumus Effendie (1979):

$$
\mathrm{W}=\mathrm{W} 1-\mathrm{W} 2
$$

Keterangan:

$\mathrm{W}=$ Pertumbuhan berat mutlak $(\mathrm{g})$

$\mathrm{W} 1=$ Berat ikan pada waktu akhir $(\mathrm{cm})$

$\mathrm{W} 2=$ Berat ikan pada waktu awal $(\mathrm{cm})$

Perkembangan Ikan

Pengamatan perkembangan benih ikan lele dilakukan secara langsung pada lokasi pemeliharaan dengan mengamati perkembangan keaktifan ikan dan kecepatannya melahap pakan mulai dari awal

pemeliharaan sampai akhir pemeliharaan.

\section{Analisis data}

Data yang diperoleh dianalisa menggunakan analysis of variance (ANOVA).

\section{HASIL DAN PEMBAHASANI \\ Hasil \\ Pertumbuhan Benih Ikan Lele Dumbo}

Berdasarkan hasil pengamatan pertambahan pertumbuhan ikan lele dumbo (Clarias gariepinus) yang diberi pakan alami cacing tanah dan pakan pelet, hasil pengukuran paramenter 
panjang total, tinggi badan, berat total, panjang kepala, panjang sirip dorsal dan panjang ekor disajikan dalam Tabel 1 di bawah ini.

Tabel 1. Hasil Pengukuran Parameter Pertumbuhan Benih Ikan Lele

\begin{tabular}{|c|c|c|c|c|c|c|}
\hline \multirow[t]{2}{*}{ No } & \multirow{2}{*}{$\begin{array}{c}\text { Parameter } \\
\text { yang diamati }\end{array}$} & \multirow[t]{2}{*}{ Jenis Pakan } & \multicolumn{4}{|c|}{$\begin{array}{l}\text { Pemeliharaan Minggu ke (Rata-rata } \pm \text { SD) dalam satuan } \\
\qquad \mathrm{cm}\end{array}$} \\
\hline & & & 0 & 1 & 2 & 3 \\
\hline \multirow{2}{*}{1} & \multirow{2}{*}{$\begin{array}{l}\text { Panjang total } \\
(\mathrm{cm})\end{array}$} & Pakan Cacing & $4.18 \pm 0.20$ & $4.72 \pm 0.33$ & $5.48 \pm 0.41$ & $6.52 \pm 0.64$ \\
\hline & & Pakan Pelet & $3.94 \pm 0.24$ & $4.22 \pm 0.24$ & $4.68 \pm 0.23$ & $5.24 \pm 0.25$ \\
\hline \multirow{2}{*}{2} & \multirow{2}{*}{$\begin{array}{c}\text { Berat badan } \\
\text { (gr) }\end{array}$} & Pakan Cacing & $1.4 \pm 0.32$ & $1.92 \pm 0.23$ & $2.56 \pm 0.29$ & $3.22 \pm 0.33$ \\
\hline & & Pakan Pelet & $1.24 \pm 0.18$ & $1.42 \pm 0.20$ & $1,72 \pm 0.21$ & $2.16 \pm 0.23$ \\
\hline \multirow{2}{*}{3} & \multirow{2}{*}{$\begin{array}{l}\text { Tinggi badan } \\
(\mathrm{cm})\end{array}$} & Pakan Cacing & $0.66 \pm 0.11$ & $0.92 \pm 0.15$ & $1.2 \pm 0.19$ & $1.48 \pm 0.31$ \\
\hline & & Pakan Pelet & $0.38 \pm 0.17$ & $0.56 \pm 0.24$ & $0.84 \pm 0.25$ & $1.1 \pm 0,15$ \\
\hline \multirow{2}{*}{4} & \multirow{2}{*}{$\begin{array}{c}\text { Panjang kepala } \\
(\mathrm{cm})\end{array}$} & Pakan Cacing & $1.16 \pm 0.11$ & $1.36 \pm 0.13$ & $1.56 \pm 0.15$ & $2.14 \pm 0.24$ \\
\hline & & Pakan Pelet & $0.94 \pm 0.15$ & $1.14 \pm 0.11$ & $1.32 \pm 0.13$ & $1.54 \pm 0.20$ \\
\hline \multirow{2}{*}{5} & \multirow{2}{*}{$\begin{array}{c}\text { Panjang sirip } \\
\text { dorsal }(\mathrm{cm})\end{array}$} & Pakan Cacing & $2.52 \pm 0.19$ & $2.84 \pm 0.15$ & $3.34 \pm 0.24$ & $3.98 \pm 0.48$ \\
\hline & & Pakan Pelet & $2.66 \pm 0.11$ & $2.74 \pm 0.08$ & $2.88 \pm 0.04$ & $3 \pm 0.1$ \\
\hline \multirow{2}{*}{6} & \multirow{2}{*}{$\begin{array}{c}\text { Panjang ekor } \\
(\mathrm{cm})\end{array}$} & Pakan Cacing & $0.16 \pm 0.05$ & $0.32 \pm 0.04$ & $0.52 \pm 0.15$ & $0.72 \pm 0.16$ \\
\hline & & Pakan Pelet & $0.11 \pm 0.04$ & $0.18 \pm 0.08$ & $0.32 \pm 0.10$ & $0.56 \pm 0.18$ \\
\hline
\end{tabular}

Perkembangan benih ikan lele

Berdasarkan hasil pengamatan perkembangan benih ikan lele dumbo (Clarias gariepinus) yang diberi pakan alami yaitu cacing tanah dan pakan pelet. Perkembangan benih ikan lele diamati dalam hal keaktifan bergerak, keaktifan menyantap makanan dari dua jenis pakan yaitu pakan caning tanah dan pakan pelet yang dijual komersial. Hasil pengamatan perkembangan benih ikan lele yang diberi pakan alami cacing tanah dan pakan pelet disajikan dalam tabel 2.

\section{Mikroklimat Lingkungan}

Berdasarkan hasil pengukuran mikroklimat, suhu air yang digunakan untuk pemeliharaan benih ikan lele antara $26-27{ }^{\circ} \mathrm{C}$, dan ph air adalah 7. Hasil pengukuran mikroklimat air pemeliharaan ikan lele dumbo disajikan dalam bentuk tabel dibawah ini. Hasil pengukuran mikroklimat disajikan dalam Tabel 3. Mikroklimat air dalam penelitian ini merupakan variabel kontrol yang dijaga dan dibuat sama agar tidak mempengaruhi variabel bebas yaitu pertumbuhan dan perkembangan ikan lele.

Tabel 2. Hasil pengamatan perkembangan aktivitas fisik benih ikan lele

\begin{tabular}{|c|c|c|c|c|}
\hline \multirow[b]{2}{*}{$\begin{array}{c}\text { Minggu } \\
\text { ke- }\end{array}$} & \multicolumn{2}{|c|}{ Pakan cacing tanah } & \multicolumn{2}{|l|}{ Pakan pellet } \\
\hline & $\begin{array}{l}\text { Gerak } \\
\text { an }\end{array}$ & $\begin{array}{l}\text { Keaktifan } \\
\text { menyantap } \\
\text { pakan }\end{array}$ & $\begin{array}{l}\text { Keaktifan } \\
\text { bergerak }\end{array}$ & $\begin{array}{l}\text { Keaktifan } \\
\text { menyantap } \\
\text { pakan }\end{array}$ \\
\hline 1 & $\begin{array}{l}\text { Aktif, } \\
\text { perger } \\
\text { akan } \\
\text { cepat }\end{array}$ & $\begin{array}{l}\text { Aktif, pakan } \\
\text { langsung } \\
\text { disantap }\end{array}$ & $\begin{array}{l}\text { Kurang } \\
\text { aktif, } \\
\text { pergerakan } \\
\text { lambat }\end{array}$ & $\begin{array}{l}\text { Kurang aktif, } \\
\text { pakan tidak } \\
\text { langsung } \\
\text { disantap }\end{array}$ \\
\hline 2 & $\begin{array}{l}\text { Aktif, } \\
\text { perger } \\
\text { akan } \\
\text { cepat }\end{array}$ & $\begin{array}{l}\text { Aktif, pakan } \\
\text { langsung } \\
\text { disantap }\end{array}$ & $\begin{array}{l}\text { Aktif, } \\
\text { pergerakan } \\
\text { cepat }\end{array}$ & $\begin{array}{l}\text { Aktif, pakan } \\
\text { langsung } \\
\text { disantap }\end{array}$ \\
\hline 3 & $\begin{array}{l}\text { Sangat } \\
\text { aktif }\end{array}$ & $\begin{array}{l}\text { Sangat aktif, } \\
\text { makanan } \\
\text { dengan cepat } \\
\text { disantap }\end{array}$ & $\begin{array}{l}\text { Aktif, } \\
\text { pergerakan } \\
\text { cepat. }\end{array}$ & $\begin{array}{l}\text { Aktif, pakan } \\
\text { langsung } \\
\text { disantap }\end{array}$ \\
\hline
\end{tabular}


Tabel 3. Hasil pengukuran mikroklimat lingkungan

\begin{tabular}{ccccc}
\hline \multirow{2}{*}{$\begin{array}{c}\text { Ulangan } \\
\text { ke- }\end{array}$} & \multicolumn{2}{c}{$\begin{array}{c}\text { Pakan cacing } \\
\text { tanah }\end{array}$} & \multicolumn{2}{c}{ Pakan pellet } \\
\cline { 2 - 5 } & $\begin{array}{c}\text { Suhu } \\
\left({ }^{\circ} \mathrm{C}\right)\end{array}$ & $\mathrm{Ph}$ & $\begin{array}{c}\text { Suhu } \\
\left({ }^{\circ} \mathrm{C}\right)\end{array}$ & $\mathrm{Ph}$ \\
\hline 1 & 27 & 7 & 26 & 7 \\
\hline 2 & 26 & 7 & 27 & 7 \\
\hline 3 & 26 & 7 & 27 & 7 \\
\hline 4 & 27 & 7 & 27 & 7 \\
\hline 5 & 27 & 7 & 27 & 7 \\
\hline
\end{tabular}

\section{Pembahasan}

Berdasarkan hasil pengamatan pertumbuhan dan perkembangan ikan lele dumbo yang diberi pakan alami (cacing tanah) dan pakan buatan (pelet) di Desa Tugang, Kecamatan Kelapa, Kabupaten Bangka Barat memiliki perbedaan yang nyata (Gambar 1 dan Gambar 2). Pertumbuhan panjang tertinggi dalam perlakuan dan ulangan adalah $3 \mathrm{~cm}$ dan terendah $1,1 \mathrm{~cm}$. Pertumbuhan panjang terendah adalah ikan lele dumbo yang diberi pakan cacing tanah pada ulangan keempat, sedangkan pertumbuhan panjang terendah adalah ikan lele dumbo yang diberi pakan pelet pada ulangan keempat. Dari hasil pengamatan yang dilakukan, dapat diketahui bahwa pertumbuhan berat benih ikan lele dumbo (Clarias gariepinus) tertinggi adalah $2 \mathrm{~g}$ dan terendah $0,8 \mathrm{~g}$. Pertumbuhan berat tertinggi terdapat pada benih ikan lele dumbo yang diberi pakan cacing tanah pada ulangan keempat, sedangkan yang terendah terdapat pada benih ikan lele yang diberi pakan pellet pada ulangan kesatu dan kedua. Selain pertumbuhan panjang dan berat ikan, hal lain yang dapat diamati untuk mengetahui pertumbuhan benih ikan lele dumbo (Clarias gariepinus) adalah morfologi tubuh, panjang kepala, panjang sirip dorsal, panjang ekor dan tinggi badan. Berikut disajikan beberapa gambar pengamatan pertumbuhan benih ikan lele selama pemeliharaan (Gambar 1 dan Gambar 2).

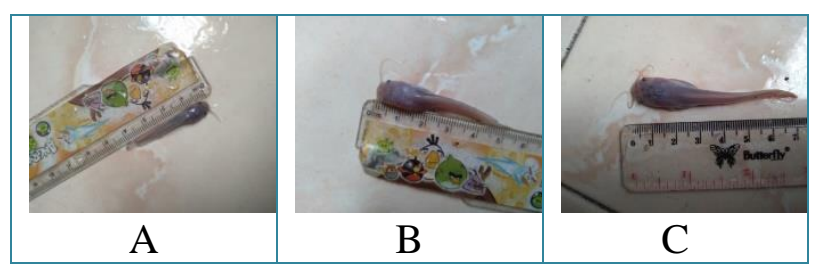

Gambar 1. Benih ikan lele pakan cacing tanah: A) minggu ke-1; B) minggu ke-2; C) minggu ke-3

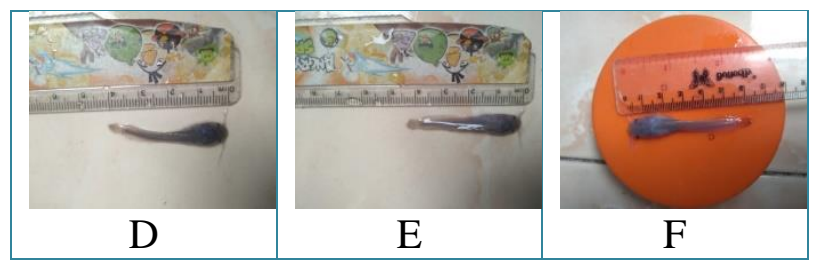

Gambar 2. Benih ikan lele pakan pelet: D) minggu ke-1; E) minggu ke-2; F) minggu ke-3

Hasil pengamatan terhadap pertumbuhan dan perkembangan benih ikan lele yang diberi pakan alami (cacing tanah) dan pakan buatan menunjukkan bahwa benih ikan lele yang diberi pakan alami memiliki laju pertumbuhan yang lebih cepat jika dibandingkan dengan benih ikan lele yang diberi pakan pelet. Hasil uji ANOVA pemberian pakan berbeda menunjukkan pengaruh nyata terhadap bobot pertumbuhan panjang total, berat total, panjang kepala, dan panjang sirip dorsal ( $\mathrm{F}$ hitung $>\mathrm{F}$ tabel). Sedangkan untuk tinggi badan dan panjang ekor tidak berpengaruh nyata $(\mathrm{F}$ hitung $<\mathrm{F}$ tabel). Hasil uji ANOVA untuk paramenter panjang total nilai $\mathrm{F}$ hitung 12,48 dan $\mathrm{F}$ tabel 5,31 , paramenter berat total nilai $\mathrm{F}$ hitung 12,96 dan $\mathrm{F}$ tabel 5,31, paramenter tinggi badan nilai $\mathrm{F}$ hitung 0,5 dan $\mathrm{F}$ tabel 5,31, parameter panjang kepala nilai $\mathrm{F}$ hitung 10,02 dan $F$ tabel 5,31, parameter panjang sirip dorsal nilai $\mathrm{F}$ hitung 23,14 dan $\mathrm{F}$ tabel 5,31 , parameter panjang ekor nilai $\mathrm{F}$ hitung 1,1 dan $F$ tabel 5,31. Hal ini sejalan dengan 
hasil penelitian Azis dan Simanjuntak (2019), yang menunjukkan bahwa pemberian pakan alami yaitu cacing sutra menghasilkan pertumbuhan yang optimal untuk pertumbuhan ikan lele jika dibandingkan dengan perlakuan lainya. Selain itu, hasil penelitian Novita dan Nurlita (2013) juga menunjukkan bahwa pemberian pakan alami dan pakan buatan memiliki pengaruh yang cukup besar terhadap laju pertumbuhan spesifik ikan. Pemberian pakan alami cacing sutra memberikan hasil pertumbuhan ikan terbaik. Hal tersebut dikarenakan kualitas pakan mempengaruhi laju pertumbuhan dan perkembangan benih ikan. Ikan lele yang diberi pakan cacing tanah memiliki laju pertumbuhan dan perkembangan yang tinggi dikarenakan cacing tanah memiliki kandungan nutrisi yang cukup tinggi yang dibutuhkan oleh tubuh ikan, seperti protein. Menutut Amalia (2013), pakan yang memiliki kandungan protein yang tinggi dapat dimanfaatkan oleh ikan untuk pertumbuhan. Selain itu, benih ikan lele yang diberi pakan alami cacing lebih aktif menyantap pakan jika dibandingkan dengan benih ikan lele yang diberi pakan pelet.

Pertumbuhan ikan sangat erat kaitannya dengan ketersediaan protein dalam pakan. Hal ini dikarenakan protein merupakan sumber energi bagi ikan dan protein merupakan nutrisi yang sangat dibutuhkan ikan untuk pertumbuhan. Menurut Novita dan Nurlita (2013), protein akan mempengaruhi pertumbuhan ikan. Tinggi rendahnya protein dalam pakan dipengaruhi oleh kandungan energi nonprotein yaitu yang berasal dari karbohidrat dan lemak. Cacing memiliki kandungan nutrisi yang tinggi yaitu $57 \%$ protein, $13,30 \%$ lemak dan 2,04\% karbohidrat. Sedangkan Pakan pellet biasanya dibuat dalam bentuk tertentu sehingga dapat menarik ikan dan mempermudah ikan dalam melahapnya. Pakan pellet komersial yang biasa digunakan mengandung $33 \%$ protein,
$5 \%$ lemak dan 6\% karbohidrat (Julendra 2007).

Pertumbuhan dan perkembangan benih ikan lele dumbo (Clarias gariepinus) juga dipengaruhi oleh faktor mikroklimat. Mikroklimat yang diukur dalam penelitian ini adalah Suhu dan $\mathrm{pH}$ air. Suhu dan $\mathrm{pH}$ sangat berpengaruh terhadap pertumbuhan dan perkembangan benih ikan lele dumbo (Clarias gariepinus). Menurut Effendie (2002), terdapat beberapa faktor yang mempengaruhi pertumbuhan dan perkembanganikan lele, yaitu faktor internal dan faktor eksternal. Faktor internal yang mempenganruhi seperti genetik, sedangkan faktor eksternal yang mempengaruhi adalah kondisi lingkungan. Suhu dalam suatu ekosistem seperti air sangat berpengaruh terhadap kelangsungan hidup makhluk hidup yang ada didalamnya. Pertumbuhan dan perkembangan ikan lele dipengaruhi juga dipengaruhi oleh suhu air pada lokasi pemeliharaannya. Menurut Zonneveld et. al (1991), suhu adalah salah satu faktor yang mempengaruhi laju metabolism dan kelarutan gas dalam air. Semakin tinggi suhu, akan meningkatkan laju metabolisme ikan sehingga respirasi yang terjadi akan semakin cepat. Dari hasil penelitian, suhu air yang digunakan untuk pemeliharaan ikan lele dumbo (Clarias gariepinus) berkisar antara $26-27^{\circ} \mathrm{C}$ yang merupakan suhu ideal untuk pemeliharaan ikan lele. Hal ini sesuai dengan pendapat Arifin (1991), suhu yang optimum bagi pertumbuhan ikan lele berkisar antara 25$32^{\circ} \mathrm{C}$. Faktor berikutnya yaitu faktor $\mathrm{pH}$ yang memiliki pengaruh yang cukup besar terhadap pertumbuhan dan perkembangan benih ikan lele. Menurut Suyanto (1999), pH memegang peranan penting dalam bidang perikanan karena berhubungan dengan kemampuan untuk tumbuh. $\mathrm{PH}$ air yang digunakan untuk pemeliharaan ikan lele pada penelitian ini adalah 7,2. Menurut Arifin (1991), nilai pH yang baik untuk 
pemeliharaan ikan lele berkisar antara 6,58,5 . Tinggi rendahnya suatu $\mathrm{pH}$ dalam perairan salah satunya di pengaruhi oleh jumlah kotoran dalam lingkungan perairan khususnya sisa pakan dan hasil metabolisme

Berdasarkan hasil pengamatan, benih ikan lele dumbo (Clarias gariepinus) yang diberi pakan alami (cacing tanah) menunjukkan perkembangan yang lebih cepat dibandingkan dengan benih ikan lele dumbo (Clarias gariepinus) yang diberi pakan pelet. Perkembangan benih ikan lele dumbo (Clarias gariepinus) yang diamati adalah keaktifan bergerak dan keaktifan saat menyantap pakan. Benih ikan lele dumbo (Clarias gariepinus) yang diberi pakan alami cacing tanah lebih cepat mengalami perkembangan dibandingkan benih ikan lele dumbo (Clarias gariepinus) yang diberi pakan pelet. Benih ikan lele dumbo (Clarias gariepinus) yang diberi pakan alami (cacing tanah) mulai aktif menyantap pakan mulai dari awal pemelihraan, sedangkan benih ikan lele dumbo (Clarias gariepinus) yang diberi pakan pelet mulai aktif menyantap pakan pada minggu kedua pemeliharaan pengamatan. Berikut disajikan beberapa gambar pengamatan perkembangan benih ikan lele selama pemeliharaan.

\section{KESIMPULAN}

Berdasarkan hasil penelitian yang telah dilakukan, dapat ditarik kesimpulan bahwa Pemberian pakan yang berbeda berpengaruh terhadap Pertumbuhan dan perkembangan benih ikan lele dumbo. Benih ikan lele dumbo (Clarias gariepinus) yang diberi pakan alami cacing tanah memiliki laju pertumbuhan dan perkembangan yang lebih cepat dibandingkan dengan benih ikan lele yang diberi pakan pelet. Hasil uji ANOVA pemberian pakan berbeda menunjukkan pengaruh nyata terhadap bobot pertumbuhan panjang total, berat total, panjang kepala, dan panjang sirip dorsal (F hitung $>\mathrm{F}$ tabel). Sedangkan untuk tinggi badan dan panjang ekor tidak berpengaruh nyata ( $\mathrm{F}$ hitung $<\mathrm{F}$ tabel).

\section{UCAPAN TERIMA KASIH}

Terima kasih kepada Program Studi Biologi Universitas Bangka Belitung yang telah memfasilitasi kegiatan Penelitian.

\section{DAFTAR PUSTAKA}

Amalia R. 2013. Pengaruh Penggunaan Papain Terhadap Tingkat Pemanfaatan Protein

Pakan dan Pertumbuhan Lele

Dumbo (Clarias gariepinus). Semarang:

Fakultas Perikanan dan Kelautan, Universitas Diponegoro

Arifin MZ. 1991. Budidaya Lele. Semarang: Dohara Prize.

Aziz, Simanjuntak RF. 2019. Pengaruh Pemberian Pakan Alami Yang Berbeda Terhadap Pertumbuhan Larva Ikan Lele Dumbo (Clarias gariepinus). Jurnal Akuakultur Rawa Indonesia. 7(2): 133122.

Effendi INJ, Bugri, Widanarni. 2006. Pengaruh Padat Penebaran Terhadap Kelangsungan Hidup dan Pertumbuhan Benih Ikan Gurami Osphronemus gourami ukuran 2 cm. Jurnal Akuakultur Indonesia.

Effendie MI. 1979. Metode Biologi Perikanan. Jakarta: Gramedia Pustaka Utama.

Effendie MI. 2002. Biologi Perikanan. Yogyakarta: Yayasan Pusaka Nusantara.

Julendra H. 2007. Uji In Vitro Penghambat Aktivitas Escherichia coli dengan Tepung Cacing Tanah (Lumbricusrubellus). Media perikanan. 30 (1).

Mudjiman A. 2008. Makanan ikan. Jakarta: Penebar Swadaya.

Novita MA, Nurlita A. 2013. Pengaruh Pemberian Pakan Alami dan Pakan Buatan Terhadap pertumbuhan Ikan Betutu

(Oxyeleotris marmorota) pada Skala Laboratorium. Jurnal SAINS dan Seni POMITS. 2(1). Hal: $\quad$ 2337-3520

Suyanto SR. 1999. Budidaya Ikan Lele. Jakarta: Penebar Swadaya.

Syafruddin. 2016. Analisis kadar protein ikan lele yang beredar di pasar tradisional dengan menggunakan metode kjeldahl. Indonesia timur: Universitas Indonesia Timur.

Zonneveld N. 1991. Budidaya Ikan. Jakarta: Gramedia. 